\title{
THE PURSUIT OF HAPPINESS AS A UNIVERSAL HUMAN RIGHT
}

In Happiness And Contemporary Society : Conference Proceedings Volume (Lviv, March, 20-21, 2021). Lviv: SPOLOM, 2021. P. 124-129. https://doi.org/10.31108/7.2021.27

ISBN 978-966-919-697-2 
https://doi.org/10.31108/7.2021.27

GUVEN Ada

Phd Candidate, University of Tirana (Tirana, Albania)

HAJDINI Bojana

PhD, Assistant Professor Lecturer at Law Department, Epoka University (Tirana, Albania)

\section{THE PURSUIT OF HAPPINESS AS A UNIVERSAL HUMAN RIGHT}

The article aims to give a brief review of the concept of the pursuit of happiness, its' meaning and the role of individuals and the state that can contribute to the achievement of individual happiness by providing the legal, financial, and institutional resources. Further the article analyze the first constitutions that specifically foreseen the pursue of happiness in their provisions and argued that constantly remind the public institutions of the intentions in respecting the natural, unalienable, and sacred human rights that are necessary for the maintenance of order and the happiness of all. In the last part of the article we have studied some of the modern European constitutions and concluded that in difference from the Declarations of two centuries before, the term of happiness has been replaced with a list of rights that implicitly oblige governments to secure to all of its' citizens extended quality of happiness.

Key words: pursuit of happiness, human rights, constitution

The meaning of happiness

Happiness has always been a debated term regarding what really does it mean. Epicurus (341 - 270 BC) being the first dealing with the topic specifically in the "Letter on happiness", addressed to Menoeceus, a character from Greek mythology, "Happiness is to be what nature has foreseen for us" (Epiricus, 1994).

For Aristotle (384-322 BC), happiness is an end to be achieved: there are two characteristics that must be present in the notion of happiness. Happiness must be an end and not a means; the other is the clarification that happiness is a reason for living that must be pursued for what it really is and not to get something else. Pursuing our goals without losing the path of virtue and with the habit of doing good means achieving happiness (Chang, 2008).

A different opinion that stood out for the time it was expressed, was argued by Kant, the German philosopher, in 1791. He stated that the foundation of any Civil State should be established by three principles: individual liberty, equality under the law, and self-dependency for voting rights (Guyer, 2000). Kant has analyzed happiness from another aspect, such as that everybody has the right to pursue their own vision of happiness without interference by the State: "No one has a right to compel me to be happy in the peculiar way in which he may think of the well-being of other men; but everyone is entitled to seek his own happiness in the way that seems to him best, if it does not infringe the liberty of others in striving after a similar end for themselves ...". In this prospect, Kant defended the perspective of liberalism and constitutionalism, and 
according to him the State must guarantee without interference, the freedom of life choices, that is, the autonomy of the individual in determining his own existence.

From what we have seen above, the question that really arises is: "what does happiness mean?". The dictionary definition of "happiness" is specified to be the positive mood of those who believe that all their desires are satisfied, or as the complete experience of each fulfillment. In essence, it would be a set of emotions and sensations of the body and intellect capable of providing well-being and joy for a shorter or longer period of our life, and which would also be achieved through the acceptance of the different and the tranquility with others (Oxford English Dictionary, 2021).

Therefore, it can be argued that the State can contribute to the achievement of individual happiness by providing the legal, financial, and institutional resources that allow or facilitate the achievement of this goal by individuals. More precisely, the State will have the duty to not approve rules or measures that preclude, without justifying reason, the achievement of individual happiness, as well as, in the context of what is possible, it will have to positively put in place norms or measures that make easier the achievement of the result by individuals. However, determining what individual happiness should consist of, and how to achieve it is not the task of the State or other public entities (Guyer, 2000).

Evolution of the right to happiness as a legal concept

The concept of the right to happiness can be traced in the famous Declaration of Independence of the United States of America of 1776, where it was engraved in stone that: "We hold these truths to be self-evident, that all men are created equal, that they are endowed by their Creator with certain unalienable Rights, that among these are Life, Liberty and the pursuit of Happiness; -That whenever any Form of Government becomes destructive of these ends, it is the Right of the People to alter or to abolish it, and to institute new Government, laying its foundation on such principles and organizing its powers in such form, as to them shall seem most likely to effect their Safety and Happiness" (Jefferson, 2018). The Founding Fathers have referred to this historical episode, observing that it is a strong, explicit affirmation, which attributes to the individual happiness of people, almost impossible to unambiguously decline, the nature of an inviolable right constitutionally guaranteed (Erler, 2019). In the Declaration, "the pursuit of happiness" is listed with the other inseparable, inviolable, and unalienable rights of "life" and "liberty". These are fundamental rights essential to existence, states of being. If happiness is akin to life and liberty, then we are dealing with profound and extended qualities of life and it's a primary duty of governments to secure to all of its' citizens extended quality of happiness (Charles, 2011). The Declaration represents the first document that has legalized the time "the right to happiness" in the story of the rise of democratic constitutions and the founding norm of a state. This is a strong, explicit statement, which not for the first time it attributes to the individual happiness of people which does not have a univocal definition - the nature of an inviolable right constitutionally guaranteed. Right to the pursuit of which the governments that derive their just powers from the consent of the governed and that whenever any form of government tends to deny these ends, the people have the right to change or abolish it and to establish a new government based on these principles and to organize their powers in the form that seems to the people best suited to procure their safety and happiness. 
A few years after the Declaration of Independence of the United States of America, the national assembly of France has passed the Declaration of Human and Civic Rights of 1789 which for the first time in Europe has specifically mentioned the term "happiness" with the only difference from United States that it is specified not in its articles but only in the preamble of the Declaration thus "The representatives of the French People, ... considering ignorance, forgetfulness or contempt of the rights of man to be the only causes of public misfortunes and the corruption of Governments, have resolved to set forth, in a solemn Declaration, the natural, unalienable and sacred rights of man...; to the end that the demands of the citizens, founded henceforth on simple and incontestable principles, may always be directed toward the maintenance of the Constitution and the happiness of all." (Henkin, 1989). This is a powerful Declaration addressed to the legislature and the executive to constantly remind the public institutions of the intentions in respecting the natural, unalienable, and sacred human rights that are necessary for the maintenance of order and the happiness of all. Therefore, happiness is defined to be part of sacred human rights.

Another document useful to support the proposal for a constitutionalizing of the right to happiness, is accepted to be the United Nations Resolution A / RES / 66/281 of July 2012 (United Nations, 2012 ); more commonly known as the resolution that established World Happiness Day. From the point of view of the sources of the law, it is a soft law act with a fundamental value for the recognition of this right. The Resolution clearly defines the intent of the Nations: "Recognizing the relevance of happiness and well-being as universal goals and aspirations in the lives of human beings around the world and the importance of their recognition in public policy objectives" inviting all countries adherents to observe " the International Day of Happiness in an appropriate manner, including through education and public awareness-raising activities" (United Nations, 2012 ). It is precisely in this way that the General Assembly consciously declares that the pursuit of happiness is a fundamental goal of humanity.

In the document, after clarifying that the pursuit of happiness is a fundamental purpose of humanity, it is emphasized that it is very important to recognize the relevance of happiness and well-being in the objectives of public policies; as well as the need for a more inclusive, equitable and balanced approach to economic growth that promotes sustainable development, the eradication of poverty and, precisely, the happiness and well-being of every person (United Nations, 2020). The United Nations seems to want to link happiness to the economic dimension, to greater social justice, to a certain type of progress, and identify in public policies, implemented by States or by public regulators, the tool to be used to achieve this goal. Happiness understood as something concrete that everyone must be able to afford, including the less well-off who, coming out of the state of need, could automatically enter the category of "happy".

The right to happiness in modern constitutions

The expression happiness it is not mentioned specifically in modern constitutions, Legislators rather than that term have preferred to define in the articles and the preambles of constitutions that they recognize the right to self-determination of people, the right of all people to be equal and the duty of public institutions to ensure the ideal of liberty, equality and fraternity. 
The France's Constitution of 1958 has foreseen in its preamble and the first article that the main duty of the state is to ensure that its citizens are equal before the law regardless of origin, race, and religion and provide the same access to women and men to elective offices and posts (Henkin, 1989).

The Basic Law of the Federal Republic of Germany which has been ratified after WWII on May 1949, differs from the constitution of France because the first part of it Article1 to 19 have amended the personal freedoms that give people the right and opportunity to construct their own lifestyle choices and is exclusively devoted to the protection of individual liberties. The first article has specified in its text the expression "human dignity" and the need for using that exact term urged from the necessity of advancing human welfare, happiness, and prosperity alongside defending the liberty of individuals (Wolczuk, 2001). Whilst in the preamble of the Basic Law is embodied the duty and responsibilities that German people have before God and all man, which conveys the determination to promote world peace in a time where Germany has been an invading power in the war. The first part of this constitution obliges all state authority to respect and protect human rights, peace, and justice not only within borders but also in all the world. The second article specifies the personal freedoms to be the right to free development of one's personality and the right to life and physical integrity. However, this provision obliges its' citizens that no offense against the constitutional order or the moral law shall be allowed (Federal Republic of Germany, 2019). Thus, we can conclude that the right to happiness, is transversal to other constitutional rights.

There is no trace of the word "happiness" in the Italian constitutional text, the last reference to the "... happy nation" contained in the Albertine Statute promulgated on March 4, 1848 that remained in force until December 31, 1947, has also disappeared. The Constituent Fathers have chosen to identify Italy as "a democratic Republic founded by work". However, the Article 2, paragraph 2, of the Constitution provides that "The Republic recognizes and guarantees the inviolable rights of man, both as an individual and in the social functions where the personality takes place, and requires the fulfillment of the mandatory duties of political, economic and social solidarity", while article 3 , paragraph 2, there is an implicit reference to the right to happiness understood as "full development of the human person"." Therefore, after having established, in paragraph 1, that "All citizens have equal social dignity and are equal before the law without distinction of sex...". Italian Philosophers have argued that the citizen's right to happiness, in more general terms should be considered as a limit to the power of the State to guide their destinies, and at the same time as a vindication of the most sacred of personality rights, that of being oneself and being free to realize their ambitions (Trampus, 2008).

The constitution of Albania, in terms of the position of human rights art is built in similarity to the constitution of France. The articles that regulate the rights and the duties of the citizens are placed in the second part of the constitution. Yet, the expression "happiness" is not explicitly mentioned in the constitution's articles. However, in the preamble the legislator is committed to protect human dignity and personhood as the core of human rights protection that implicitly aim to citizens' happiness (RSH. Kuvendi, 2016). In the current state of the constitutional provision, the right to happiness is difficult to anchor to a specific provision expressed in the Constitution. Indeed, the right in question is not of the same nature as the other rights enshrined in the 
Fundamental Charter or inferred from it by way of interpretation. The constitutional interest, which for convenience we define the right to happiness, is transversal to other constitutional rights. In other words, happiness is the ratio of constitutional rights and the right to happiness can be deduced from it.

Conclusion

States have the main task to give its' citizens the possibility and opportunities of achieving individual happiness, through a series of interventions. States by their public institutions aim at providing the legal, financial, and institutional resources that allow or make easier to achieve this goal. However, citizens find themself as holders of a constitutional interest in happiness, rather than a real right.

The configuration of a right to happiness, deductible from the constitutional legislation, does not constitute the outcome of an individualistic (legal) culture, but can, on the contrary, constitute a factor of strengthening a "culture of duties" in a secularized society denoted by the tendency to the maximize the expression of one's individuality.

Therefore, considering happiness as a condition determined by different factors for each individual, it becomes clear how it can be impossible for States to be able to guarantee it in the same way to all citizens, as it would not be possible with the tools it has at their disposal. However, before stating that it would be impossible to include this aspect in modern Constitutions, it is first necessary to verify in what terms the right to happiness can be configured within the main document that are the base of all legislation. Although, based on the mere analysis done to modern constitutions, it can be deducted that it would be impossible to draft legislation that is suitable for every citizen, one could rather hope for a "constitutional interest in happiness", also considering how this is in fact a cross-cutting interest that unites the various rights already present in the constitutional texts. Therefore, it can be observed that even a failure to fulfill this condition can lead to a condition of citizen dissatisfaction, which would therefore go against the primary duty of the State. Thus, even if "happiness" is never mentioned as a specific word it is necessary to recognize how the interest in happiness is logically correlated to the different constitutional rights, and can therefore be considered to all intents and purposes in relation to the other rights mentioned in the constitutional provisions, and consequently an important point which, can be added to modern Constitutions.

\section{REFERENCES}

1. Chang, L. (2008). Aristotle on Happiness. Riga: VDM Verlag Dr. Mueller e.K.

2. Charles, P. J. (2011). Restoring "Life, Liberty, and the Pursuit of Happiness" in Our Constitutional Jurisprudence: An Exercise in Legal History. William \& Mary Bill of Rights Journal, Volume 20 (2011-2012), Issue 2, 457-532.

3. Dennis, K. L. (2019). Healing the Wounded Mind: The Psychosis of the Modern World and the Search for the Self. Essex: Clairview.

4. Eco, U. (2014, March 26). Il diritto alla felicità. Retrieved from L'Espresso Repubblica : $\quad$ https://espresso.repubblica.it/opinioni/la-bustina-diminerva/2014/03/19/news/il-diritto-alla-felicita-1.157770/

5. Epiricus. (1994). Letter on Happiness. San Francisco: Chronicle Books. 
6. Erler, E. J. (2019). Property and the Pursuit of Happiness: Locke, the Declaration of Independence, Madison, and the Challenge of the Administrative State. New York: Rowman \& Littlefield Publishers.

7. Federal Republic of Germany. (2019, March 28). Basic Law for the Federal Republic of Germany, Federal Office of Justice. Retrieved from Federal Ministry of Justice and Consumer Protection: https://www.gesetze-iminternet.de/englisch_gg/englisch_gg.html\#p0019

8. Guyer, P. (2000). Kant on Freedom, Law, and Happiness. Cambridge: Cambridge University Press.

9. Henkin, L. (1989). Revolutions and Constitutions. Lousiana Law Review, Volume 45/ Nr.5, 1023-1056.

10. Jefferson, T. (2018). The Constitution of the United States of America, The Declaration of Independence; And the Articles f. Waashington D.C: A \& D Publishing.

11. Oxford English Dictionary. (2021, February 01). The Meaning of Happiness. Retrieved from Oxford English Dictionary: https://www.oed.com/viewdictionaryentry/Entry/84070

12. RSH. Kuvendi. (2016). Kushtetuta e Republikes se Shqiperise. Tirana: Botim i Qendrës së Botimeve Zyrtare.

13. Trampus, A. (2008). Il diritto alla felicità. Storia di un'idea. Roma-Bari: Editori Laterza.

14. United Nations. (2012, June 28 ). Resolution A/RES/66/281 adopted by the General Assembly on 28 June 2012. Retrieved from United Nations, General Assembly: http://undocs.org/A/RES/66/281

15. United Nations. (2020). World Happiness Report 2020. New York: United Nations, Sustainable Development Solutions Network.

16. Wolczuk, K. (2001). The Moulding of Ukraine: The Constitutional Politics of State Formation. Budapest: Central European University Press. 